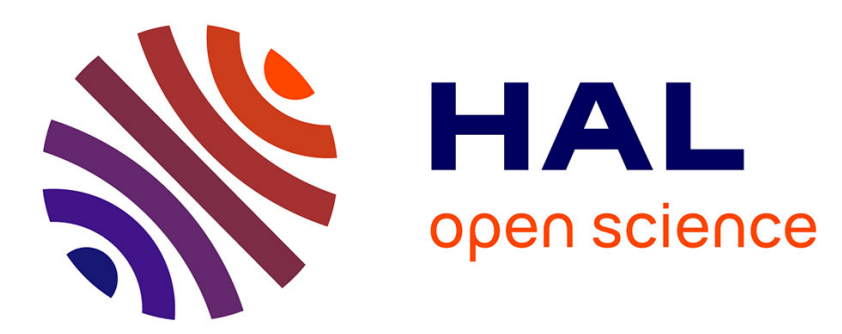

\title{
Regional surveillance of emergency-department visits for outpatient adverse drug events
}

\author{
A. Capuano, A. Irpino, M. Gallo, L. Ferrante, M. L. Illiano, B. Rinaldi, A. \\ Filippelli, F. Rossi
}

\section{- To cite this version:}

A. Capuano, A. Irpino, M. Gallo, L. Ferrante, M. L. Illiano, et al.. Regional surveillance of emergencydepartment visits for outpatient adverse drug events. European Journal of Clinical Pharmacology, 2009, 65 (7), pp.721-728. 10.1007/s00228-009-0641-8 . hal-00534952

\section{HAL Id: hal-00534952 \\ https://hal.science/hal-00534952}

Submitted on 11 Nov 2010

HAL is a multi-disciplinary open access archive for the deposit and dissemination of scientific research documents, whether they are published or not. The documents may come from teaching and research institutions in France or abroad, or from public or private research centers.
L'archive ouverte pluridisciplinaire HAL, est destinée au dépôt et à la diffusion de documents scientifiques de niveau recherche, publiés ou non, émanant des établissements d'enseignement et de recherche français ou étrangers, des laboratoires publics ou privés. 


\title{
Regional surveillance of emergency-department visits for outpatient adverse drug events
}

\author{
A. Capuano • A. Irpino • M. Gallo • L. Ferrante • \\ M. L. Illiano • B. Rinaldi • A. Filippelli • F. Rossi
}

Received: 1 August 2008 / Accepted: 19 February 2009/Published online: 18 March 2009

(C) Springer-Verlag 2009

\begin{abstract}
Aims To determine the (1) incidence of adverse drug events (ADEs) in 10 emergency department (EDs) of general hospitals in the Regione Campania (southern Italy), (2) rate of ADE-related hospital admissions, (3) drug classes most frequently involved, and (4) the types of ADEs and their frequency.

Methods We performed a cohort study of all patients attending the EDs. This study was carried out in two observational periods of 10 days each in 10 EDs. Demographic, clinical, and pharmacological data about all patients admitted to EDs were collected by trained and qualified monitors. Records related to ADEs were analyzed and validated by a specific scientific committee.

Results Of 7,861 ED visits, 96 were ADE-related. The incidence of hospitalization was higher in patients who had taken medication than in patients with a negative drug history (24.9 vs. 16.4\%). ADEs were significantly more frequent in women. Patients aged between 60 and 69 years and between 30 and 39 years were significantly more likely to experience an ADE. Serious ADEs were identified in 20 ED visits (20.8\% of total sample). Antibiotics, NSAIDs,
\end{abstract}

\footnotetext{
A. Capuano $(\bowtie) \cdot$ M. Gallo $\cdot$ L. Ferrante $\cdot$ M. L. Illiano $\cdot$

B. Rinaldi $\cdot$ A. Filippelli $\cdot$ F. Rossi

Department of Experimental Medicine,

Section of Pharmacology Leonardo Donatelli,

Center of Pharmacosurveillance and Pharmacoepidemiology,

Faculty of Medicine and Surgery, Second University of Naples,

Naples, Italy

e-mail: annalisa.capuano@unina2.it

A. Irpino

Department of European and Mediterranean Studies,

Faculty of Political Studies and Higher European

Education Jean Monnet, Second University of Naples,

Naples, Italy
}

and agents acting on the renin-angiotensin system were the drugs most often involved in ADEs. In multivariate analyses, the adjusted odds ratio was 3.4 (95\% CI: $1.07-$ 2.84) for patients taking NSAIDs, 4.78 (95\% CI: 2.26 10.12) for those taking $\beta_{2}$-adrenergic-receptor agonists, and $6.20(95 \% \mathrm{CI}: 2.74-14.06)$ for those taking $\beta$-lactam antibiotics.

Conclusion This study shows that ADEs are an important problem in industrialized countries. Moreover, it shows that ADEs affect hospital admission rates and reinforces the importance of drug-induced disease as a public health problem.

Keywords Adverse drug event · Emergency room . Antibiotics · NSAIDs · Renin-angiotensin system agents

\section{Introduction}

Adverse drug events (ADEs) are a remarkable health-care cost problem, and a major cause of morbidity and mortality [1-4]. It has been estimated that ADEs account for $0.2-$ $24 \%$ of all hospital admissions [5-7] and for $0.86-5.9 \%$ of hospital emergency-department visits [8-15]. This wide range of incidences may reflect the various types of hospitals included in the studies or methodological differences (i.e., retrospective data collection in most studies, variability in the definition of ADE among studies, and use of non-drug experts in determination of ADEs, which has been reported to lead to underestimations of ADEs by up to $50 \%$ ). Thus far, studies have focused on inpatient populations, and little is known about ADE-related emergency department (ED) visits. In fact, many studies have approached the drug-related problem by observing hospital admissions, and only a few studies have estimated the drug- 
related problems in emergency departments [9, 14, 16-18]. Moreover, most of these studies were conducted in university or tertiary hospitals, rather than in general hospitals. Evaluation of this issue from the ED perspective could contribute to a better understanding of drug-related problems that arise from general practitioner' prescriptions.

Previous studies showed that ED patients are at a high risk of adverse drug interactions and that drug-related illness is not uncommon in the emergency department [19, 20]. Moreover, recent findings have reported that one-third are likely preventable [21] and that about half could be avoided with greater prescription care [22].

In light of these findings, the primary aim of our study was to determine the incidence of ADEs in 10 EDs of general hospitals in the Regione Campania (southern Italy). Secondary endpoints were to estimate the rate of ADErelated hospital admissions, the drug classes most frequently involved in ADEs, the types of ADEs and their frequency, and to identify risk factors for ADEs requiring an $\mathrm{ED}$ visit.

\section{Methods}

We performed a cohort study of all patients attending the ED. This study was carried out in two periods of 10 consecutive days, namely, from February 28 to March 9, and from June 19 to June 28, 2005.

Ten EDs located in Campania participated in the study. Campania is a geographically and administratively welldefined Mediterranean area located on the west coast of southern Italy. In the month before the survey, monitors underwent an intensive course on theoretical and practical aspects of pharmacovigilance in ED. The monitors, who collected the data in each ED, were specialists in clinical pharmacology and were informed about the aims of the study. All ED visits were monitored, prospectively from 8:30 AM to 8:30 PM, and retrospectively, through review of ED records, during the night. All patients admitted to ED during the monitored period, regardless of their presenting complaints, were included in the study, and the monitors then tried to determine if these patients had potential ADEs on questioning.

The monitors followed each patient's progress up to diagnosis and therapy. If the patient was conscious, he/she was interviewed by the monitor after giving informed consent. If the patient was unconscious, the caregiver was interviewed after the patient had undergone a medical examination. If the patient was transferred to another department (surgery, orthopedics, etc.) for further investigation, the ED physician informed the monitor about the patient's status, and the patient's record card was updated accordingly. The following data were recorded for each individual patient on a custom-made form: sociodemographic factors (gender, age, education, ethnic group), any cigarette or alcohol use, diagnosis, drug history, type of ADE, clinical condition, and in the case of hospitalized patients, details of progress and outcome were also included [15].

Subjects were required to provide information regarding any medication taken (including over-the-counter drugs, vitamins, or herbal remedies) over the fortnight prior to the ED visit and were asked to give the drug name, dosage, method of administration, and length of therapy. All the forms were collected and recorded in the same database following each period of observation. A case-control study was nested within the prospective study to identify any possible risk factors in terms of adverse drug reactions. Case patients were defined as all patients with a probable ADE. Control patients were patients admitted to same unit (ED) as the case patients with the most similar characteristics except ADE. Thus, controls had the same level of care as the case patients.

Characteristics of hospitals involved in the study

The hospitals participating in the study are general hospitals serving different catchment areas. The hospitals are community hospitals and referral centers for the entire Campania population. At least $70 \%$ of admissions are patients whose general practitioners are located close to the hospital.

\section{Outcome measures}

According to Nebeker [23], "an adverse drug event is an injury resulting from the use of a drug. Under this definition, the term ADE includes harm caused by the drug (adverse drug reactions and overdoses) and harm from the use of the drug (including dose reductions, discontinuations of drug therapy, unsuccessful therapy also caused by noncompliance)."

In this study we considered ADEs as opposed to adverse drug reactions as the study sample group was mainly composed of outpatients. Indeed, in contrast to ADEs, medication errors are not included in adverse drug reactions. It is difficult to exclude such errors in outpatients since there is insufficient clinical monitoring and very little documentation. Patients with a previous history of drug abuse were assessed by a medical committee who considered the relationship between the event and the drug.

We recognize as preventable ADEs the adverse effects related to inappropriate prescribing, monitoring, or compliance, such as injuries resulting from the prescription of a high dosage for the patient's age or disease state, or resulting from administration of a drug to a patient with a known hypersensitivity according to some published criteria 
[24]. The findings of the physicians on the committee were reported to monitors who collected the data and reviewed the forms in order to establish the time between drug intake and the onset of symptoms, both the patient's impression and attending emergency physician's assessment of the link between the drug and its symptoms, and any previously published data on event-drug association. In the case of patients using more than one drug, the relationship with the event was assessed separately for each type of medication and drug-drug interactions were also considered.

The events were not considered ADEs when there was no temporal association between symptoms and drug treatment. Intentional drug abuses were identified but not included as ADEs. Patients were excluded from this study if a drug was administered for other than ordinary therapeutic or prophylactic purposes. Therefore, cases of suicide attempts and drug abuse were not considered.

We excluded from the study all the forms that were lacking information about gender, age, drug history, concurrent disease, outcome after ED visits, and the ADE-related drugs.

The probability that a drug caused the visit was assessed using the classification of the WHO (certain, probable/ likely, possible, unlikely, conditional/unclassified, and unassessible/unclassifiable). We graded the severity of ADE according to the World Health Organization definition: ADEs that were fatal, life-threatening, required hospitalization of the patient, or caused serious/permanent disability were deemed "serious." The diagnosis of ED visits and any associated diseases were classified using the International Classification of Disease 9th revision (ICD-9) (World Health Organization's Ninth Revision, International Classification of Diseases), while drugs were classified using the Anatomical Therapeutical Chemical (ATC) system.

\section{Statistical analysis}

We used $t$-test statistics for the comparisons of means and the chi-square test for comparing distributions. The t-test and the chi-square test (significance level of $P \leq 0.05$ ) results were used when relevant in the evaluation of the results. A stepwise logistic regression analysis was carried out in order to assess any connection between potential risk factors and ADEs. All the determinants for the outcome were identified through univariate analysis, while those with a univariable significance of $P \leq 0.05$ were grouped together in a multivariate model. All analyses were carried out using STATA 7.0 (STATA, College Station, TX).

\section{Results}

A total of 8,073 patients were admitted to the 10 EDs during the two monitoring periods. Of these, 212 cases
(6.3\%) were excluded because of incomplete demographic data, drug history, or outcome after the ED visit. Table 1 shows the demographic and clinical characteristics of the 7,861 patients included in the study.

The mean age was $44.1 \pm 20.3$ years, and $50.8 \%$ of patients were male. A total of 1,163 patients $(14.8 \%$ of the total sample) had taken medication in the 2 weeks before the study. Their mean age was $52.7 \pm 20.7$. Women were more likely to have taken at least one medication (57 vs. $41 \% ; P<0.0001)$. For patient-administered medication, 96 patients with ADEs (1.2\% of total ED visits and $8.2 \%$ of all subjects who took medication) were identified (Table 1). ADEs were more frequent in women (58.3 vs. $41.7 \%$; $P<$ $0.0001)$. Patients aged between 60 and 69 years $(P<$ $0.0001)$ and between 30 and 39 years $(P<0.0001)$ were significantly more likely to experience an ADE (Table 1). The incidence of hospitalization was significantly higher in patients who had recently taken medication than in patients with a negative drug history ( 24.9 vs. $16.4 \% ; P<0.0001)$.

Serious ADEs were identified in $20 \mathrm{ED}$ visits $(20.8 \%$ of the total sample), and these patients were hospitalized. These included seven cases (35\%) of life-threatening ADE (two cases of ropivacaine-induced angioedema, one case of beclomethasone-induced cardiogenic pulmonary edema, one case of amoxicillin-induced syncope, two cases of antidiabetic drugs-induced hypoglycemia, and one case of dexchlorpheniramine-induced anaphylactic shock). The systems/organs most frequently associated with ADEs were the skin $(34.21 \%)$ and the gastrointestinal system $(21.05 \%)$, followed by the peripheral/central nervous system (14.47\%) and the cardiovascular system (11.84\%) (Fig. 1). Table 2 lists the drugs implicated in causing ADEs. Antibiotics (18.1\%), antiinflammatory agents (13.4\%), and agents acting on the renin angiotensin system (11.4\%) were most commonly implicated. The most frequent serious ADErelated symptom was abdominal pain (four events), which was associated with thiamazole, proton-pump inhibitors, ciprofloxacin, and gestodene + ethinylestradiol; followed by confusion (three events), which was mainly associated with antiinflammatory agents. We also observed tremors in two ADE visits, which were associated with $\beta_{2}$-adrenergicreceptor agonists and anticholinergic agents (Table 3). In the monitored period, there were no reported cases of gastrointestinal hemorrhage.

The drugs most frequently related to an ADE are shown in Table 4. Five drug types were associated with more than half of ADE visits. Antibiotics were the most frequent drug category ( $26 \%$ of total ADE), followed by NSAIDs (19\%), agents acting on the renin-angiotensin system (16\%), antiasthmatics (13\%), and anticoagulants $(9.6 \%)$. Other drugs associated with ADEs were drugs for acid-related disorders (6.7\%), calcium-channel blockers, corticosteroids, and analgesics (4.8\%). Among the drug categories involved 
Table 1 Demographic and clinical characteristics of study sample and patients with an adverse drug event (ADE)

\begin{tabular}{|c|c|c|c|c|c|c|}
\hline & \multicolumn{2}{|c|}{ Total sample $(n)$} & \multicolumn{2}{|c|}{ Patients with positive drug history } & \multicolumn{2}{|c|}{ Patients with an $\mathrm{ADE}$} \\
\hline & Number & & Number & Percentage & Number & Percentage \\
\hline No. of patients & 7,861 & 100 & 1,163 & 14.8 & 96 & 1.2 \\
\hline Patients with a positive drug history & & & & 100 & & 8.2 \\
\hline Age, years $($ mean $\pm \mathrm{SD})$ & $44.1 \pm 20.3$ & & $52.7 \pm 20.7$ & & $50.8 \pm 19.2$ & \\
\hline \multicolumn{7}{|l|}{ Age groups (years) } \\
\hline $0-19$ & 726 & 9.2 & 51 & 4.5 & 3 & 3.1 \\
\hline $20-29$ & 1,322 & 16.8 & 103 & 8.9 & 7 & 7.3 \\
\hline $30-39$ & 1,288 & 16.4 & 155 & 13.3 & 22 & 22.9 \\
\hline $40-49$ & 1,110 & 14.1 & 160 & 13.8 & 16 & 16.7 \\
\hline $50-59$ & 1,012 & 12.9 & 158 & 13.6 & 13 & 13.5 \\
\hline $60-69$ & 780 & 9.9 & 138 & 11.9 & 17 & 17.7 \\
\hline $70-79$ & 611 & 7.8 & 148 & 12.7 & 7 & 7.3 \\
\hline$\geq 80$ & 396 & 5.0 & 118 & 10.1 & 8 & 8.3 \\
\hline Missing & 616 & 7.8 & 131 & 11.3 & 3 & 3.1 \\
\hline \multicolumn{7}{|l|}{ Gender } \\
\hline Females & 3,643 & 46.3 & 663 & 57.0 & 56 & 58.3 \\
\hline Males & 3,991 & 50.8 & 477 & 41.0 & 40 & 41.7 \\
\hline Missing & 227 & 2.9 & 23 & 2.0 & & \\
\hline \multicolumn{7}{|l|}{ Outcomes } \\
\hline Discharged & 6,470 & 82.3 & 875 & 75.2 & 76 & 79.2 \\
\hline Admitted & 1,385 & 17.6 & 288 & 24.8 & 20 & 20.8 \\
\hline Death & 6 & 0.1 & & & & \\
\hline
\end{tabular}

Fig. 1 Systems and organs most frequently associated with adverse drug effects

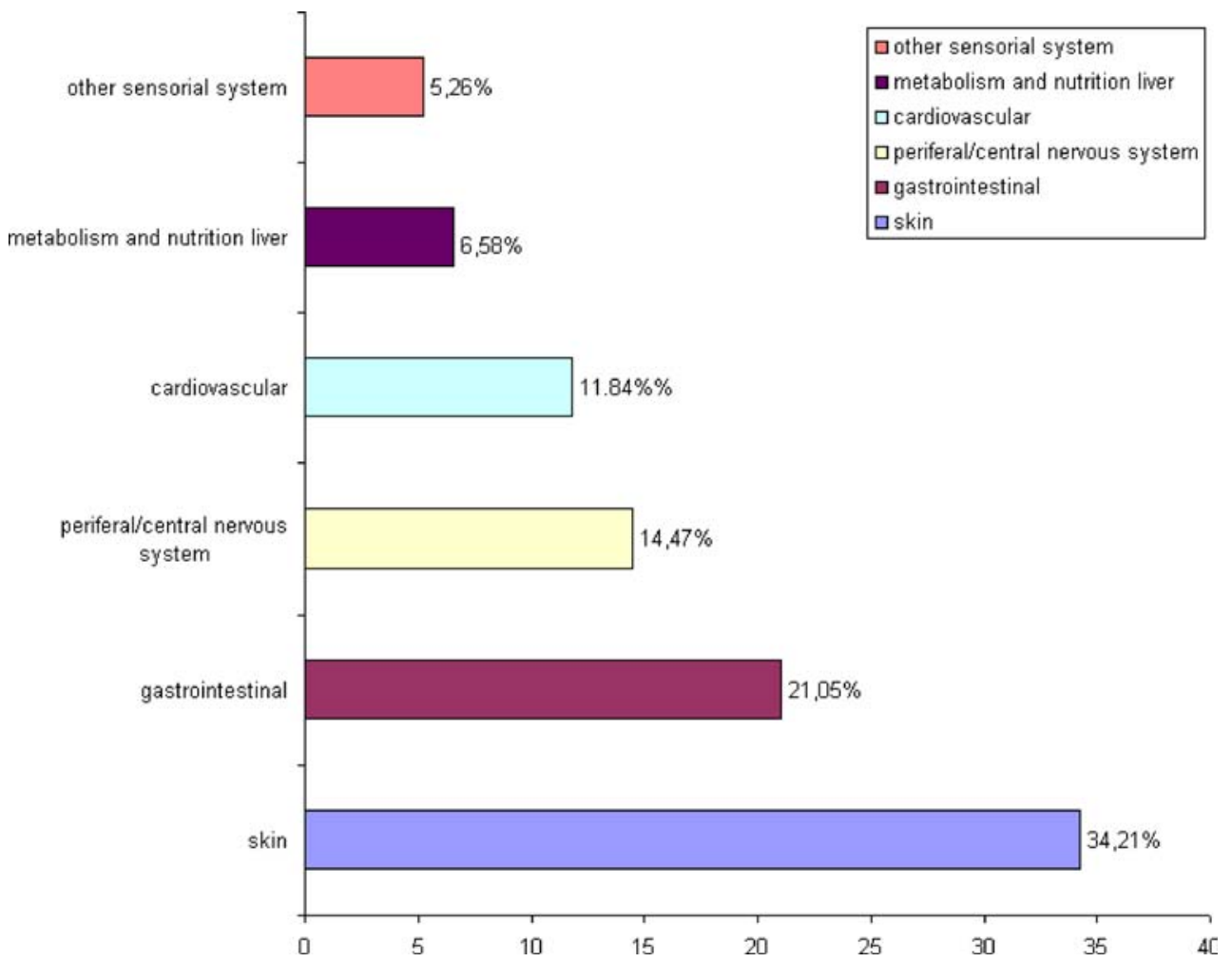


Table 2 Drugs associated with adverse drug events

\begin{tabular}{|c|c|c|c|}
\hline Drug group & $\begin{array}{l}\text { Number }(\%) \\
\text { of cases }\end{array}$ & Individual drugs $^{\mathrm{a}}(n)$ & Adverse events \\
\hline $\begin{array}{l}\text { Antibacterials for systemic } \\
\text { use }\end{array}$ & $27(18.12)$ & $\begin{array}{l}\text { Amoxicillin + clavulanic acid (6), amoxicillin } \\
\text { (6), ampicillin (4), cefazolin (3), cefixime } \\
\text { (2), ceftriaxone (1), ciprofloxacin } \\
\text { hydrochloride (2), lincomycin } \\
\text { hydrochloride (1), sulfamethoxazole }+ \\
\text { trimethoprim (4) }\end{array}$ & $\begin{array}{l}\text { Headache, confusion, diarrea, abdominal } \\
\text { pain, epigastralgia, erythema multiforme, } \\
\text { pharyngitis, urticaria, giant urticaria, giant } \\
\text { pomphi, pruritus, cutaneous rash, allergic } \\
\text { drug reaction, orticarioide reaction, syncope }\end{array}$ \\
\hline $\begin{array}{l}\text { Anti-inflammatory and } \\
\text { antirheumatic products }\end{array}$ & $20(13.42)$ & $\begin{array}{l}\text { Ibuprofen (10), ketoprofen (6), naproxen (4), } \\
\text { nimesulide (8) }\end{array}$ & $\begin{array}{l}\text { Pruritus, anemia, diarrhea, peripheral edema, } \\
\text { erythema multiforme, cutaneous rash, giant } \\
\text { pomphi, vertigo, vomiting }\end{array}$ \\
\hline $\begin{array}{l}\text { Agents acting on the renin- } \\
\text { angiotensin system }\end{array}$ & $17(11.41)$ & $\begin{array}{l}\text { Captopril + hydrochlorothiazide (4), } \\
\text { enalapril + hydrochlorothiazide (5), } \\
\text { fosinopril (6), fosinopril + } \\
\text { hydrochlorothiazide (2), irbesartan (2), } \\
\text { lisinopril (1), ramipril (2), zofenopril (2) }\end{array}$ & $\begin{array}{l}\text { Confusion, dyspepsia, edema, peripheral } \\
\text { edema, polyuria - head trauma, cough }\end{array}$ \\
\hline $\begin{array}{l}\text { Drugs for obstructive-airway } \\
\text { diseaseas }\end{array}$ & $14(9.40)$ & $\begin{array}{l}\text { Beclomethasone (4), fenoterol + ipratropium } \\
\text { bromide (5), salbutamol (1), salbutamol + } \\
\text { ipratropium bromide (2), salmeterol + } \\
\text { fluticasone (4), theophylline (1) }\end{array}$ & $\begin{array}{l}\text { Cardiogenic pulmonary edema, giant } \\
\text { urticaria, palpitation, astenia and sweating, } \\
\text { mental confusion, tremor }\end{array}$ \\
\hline Antithrombotic agents & $10(6.71)$ & $\begin{array}{l}\text { Acetylsalicylic acid (4), acenocoumarol (3), } \\
\text { warfarin (4) }\end{array}$ & $\begin{array}{l}\text { Confusion, dyspepsia, dispnea, gastralgia, } \\
\text { atrial fibrillation, pomphi, cutaneous rash }\end{array}$ \\
\hline $\begin{array}{l}\text { Drugs for acid-related disor- } \\
\text { ders }\end{array}$ & $7(4.70)$ & $\begin{array}{l}\text { Esomeprazole (2), omeprazole (2), ranitidine } \\
\text { (3), sodium alginate }+ \text { potassium } \\
\text { bicarbonate }(3)\end{array}$ & $\begin{array}{l}\text { Abdominal colic, epigastralgia, headache, } \\
\text { urticaria, pruritus, vertigo }\end{array}$ \\
\hline Calcium-channel Blockers & $5(3.36)$ & Diltiazem (2), amlodipine (5) & $\begin{array}{l}\text { Edema, hypoglycemia, hypoglycemic } \\
\text { reaction, rash, vertigo }\end{array}$ \\
\hline $\begin{array}{l}\text { Corticosteroids for systemic } \\
\text { use }\end{array}$ & $5(3.36)$ & Betamethasone (3), methylprednisolone (2) & Confusion, cutaneous rash, allergic reaction \\
\hline Analgesics & $5(3.36)$ & Paracetamol (5), tramadol (1) & Erythema multiforme, vomiting \\
\hline Beta-blocking agents & $4(2.68)$ & Bisoprolol (1), metoprolol (2), nebivolol (1) & Atrial fibrillation, syncope \\
\hline Thyroid therapy & $4(2.68)$ & Levothyroxine (2), thiamazole (2) & Peripheral edema, abdominal pain \\
\hline $\begin{array}{l}\text { Drugs for functional } \\
\text { gastrointestinal disorders }\end{array}$ & $3(2.01)$ & Domperidone (3), phloroglucinol (2) & Precordial pain, headache, spasms \\
\hline Drugs used in diabetes & $3(2.01)$ & Human insulin (2), metformin (3) & Hypoglycemia \\
\hline Antihypertensives & $3(2.01)$ & Doxazosin (3) & Dizziness, vertigo \\
\hline Urologicals & $3(2.01)$ & Alfuzosin (2), tamsulosin (1) & Asthenia, precordial pain, atrial fibrillation \\
\hline Psycholeptics & $3(2.01)$ & $\begin{array}{l}\text { Alprazolam (2), levosulpiride (1), quetiapine } \\
\text { (2) }\end{array}$ & Gastrointestinal disorders, spasms \\
\hline Cough and cold preparation & $3(2.01)$ & Acetylcysteine (3), sobrerol (3) & Cardiogenic ulmonary edema, headache \\
\hline $\begin{array}{l}\text { Antipruritics including } \\
\text { antihistamines, anesthetics }\end{array}$ & $3(2.01)$ & Dexchlorpheniramine (1), ropivacaine (2) & Anaphylactic shock, angioedema \\
\hline Antianemic preparations & $2(1.34)$ & Sodium ferric gluconate (2) & Pharyngitis \\
\hline Other hematological agents & $2(1.34)$ & Serrapeptase (2) & Pruritus \\
\hline Cardiac therapy & $2(1.34)$ & Nitroglycerin (2) & Headache \\
\hline $\begin{array}{l}\text { Sex hormones and } \\
\text { modulators of the genital } \\
\text { system }\end{array}$ & $2(1.34)$ & Gestodene + ethinylestradiol (2) & Abdominal pain \\
\hline Diuretics & $1(0.67)$ & Furosemide (1) & Cough \\
\hline $\begin{array}{l}\text { Antimycotics for systemic } \\
\text { use }\end{array}$ & $1(0.67)$ & Fluconazole (1) & Erythema multiforme \\
\hline Antiepileptics & $1(0.67)$ & Clonazepam (1) & Allergic drug reaction \\
\hline Disulfiram & $1(0.67)$ & Disulfiram (1) & Vomiting \\
\hline Total & 100.00 & & \\
\hline
\end{tabular}

${ }^{\mathrm{a}}$ In some cases, several drugs were simultaneously reported 
Table 3 Severe adverse drug events (ADEs) identified in visits to emergency departments and drugs involved

\begin{tabular}{lll}
\hline $\begin{array}{l}\text { Type of severe } \\
\text { ADE }\end{array}$ & Number & Drugs involved $^{\mathrm{a}}(n)$ \\
\hline Confusion & 3 & $\begin{array}{c}\text { Fenoterol + ipratropium bromide (1), } \\
\text { beclomethasone dipropionate (1), } \\
\text { lisinopril (2), acetylsalicylic acid (2), } \\
\text { ciprofloxacin (2), betamethasone (2) } \\
\text { Gestodene + ethinylestradiol (2), } \\
\text { thiamazole (2), ciprofloxacin } \\
\text { chlorhydrate (1), omeprazole (1), } \\
\text { esomeprazole (1) }\end{array}$ \\
Abdominal pain & 4 & $\begin{array}{l}\text { Nimesulide (2) } \\
\text { Paracetamol (2) } \\
\text { Headache }\end{array}$ \\
Vomiting & 2 & $\begin{array}{c}\text { Salbutamol (2), salbutamol + } \\
\text { ipratropium bromide (2) }\end{array}$ \\
Tremors & 2 & Ropivacaine (2) \\
\hline Angioedema & 2 &
\end{tabular}

${ }^{\mathrm{a}}$ In some cases, several drugs were simultaneously reported

in ADEs, antiasthmatics were characterized by more severe ADEs. Although they accounted for only $13 \%$ of ADE visits, they were responsible for $42.9 \%$ of serious events.

As regard to single drugs, only two medications were associated with more than 10 ADE visits: nimesulide was the most frequent, accounting for 14 ADEs $(13.4 \%$ of all $\mathrm{ADE}$ visits), and 3 of these were classified as serious. Amoxicillin/clavulanic acid was correlated with 10 events (9.6\%), one of which was serious (data not shown).

Multivariate analyses of significant correlates of ADEs in the case-control study showed that sex was not associated with ADEs. In contrast, the 30-39 age group was an independent predictive factor of $\mathrm{ADE}$ with an odds

Table 4 Number of adverse drug events (ADEs) and severe ADEs according to drug type

\begin{tabular}{llll}
\hline $\begin{array}{l}\text { ATC code } \\
\text { (III level) }\end{array}$ & Drug type $^{\mathrm{a}}$ & $\begin{array}{l}\text { Number of } \\
\text { ADE visits } \\
\text { (\% of total) }\end{array}$ & $\begin{array}{l}\text { Serious } \\
\text { ADE visits } \\
\text { (\% of total) }\end{array}$ \\
\hline J01 & Antibiotics & $27(26)$ & $4(14.3)$ \\
M01 & NSAIDs & $20(19)$ & $3(14.3)$ \\
C09 & Agents acting on the & $17(16)$ & $2(11.8)$ \\
& $\begin{array}{l}\text { renin-angiotensin } \\
\text { system }\end{array}$ & $14(13)$ & $6(42.9)$ \\
R03 & Antiasthmatics & $10(9.6)$ & $2(18.2)$ \\
B01 & Anticoagulants & $7(6.7)$ & $2(28.6)$ \\
A02 & Drugs for acid-related & disorders & - \\
C08 & Calcium-channel blockers & $5(4.8)$ & - \\
H02 & Corticosteroids & $5(4.8)$ & $2(40)$ \\
N02 & Analgesics & $5(4.8)$ & $2(40)$ \\
H03 & Thyroid therapy & $4(3.8)$ & $2(50)$
\end{tabular}

${ }^{a}$ We have considered only the 10 drug types most involved in ADE visits ratio (OR) of 2.09 (95\% CI: $1.25-3.47)$ as was comorbidity (age-adjusted OR: 5.21; 95\%CI: 3.02-8.98). In multivariate analyses, the adjusted OR was 3.4 (95\% CI: 1.07-2.84) for patients taking NSAIDs, 5.09 (95\% CI: 2.68-9.69) for those taking penicillin, 4.78 (95\% CI: 2.26-10.12) for those taking $\beta_{2}$-adrenergic-receptor agonists, and $6.20(95 \% \mathrm{CI}$ : 2.74-14.06) for those taking other $\beta$-lactam antibiotics.

\section{Discussion}

Our study, carried out in 10 EDs in Campania, showed an incidence of ADE visits of $1.2 \%$, which compares with an incidence between 0.9 and $4.3 \%$ reported in other geographic areas [25]. However, it is difficult to compare results across studies because of differences in identification criteria of ADEs, data collection periods, and study design [26]. Two meta-analyses showed an incidence of ADE between 2.4 and $3.6 \%$ in Australia and an incidence of ADE between 3.1 and $6 \%$ in the United States [25, 27].

Other studies have also shown that the incidence of adverse drug-related visits to hospital emergency departments can be considerably different depending on the definitions and methods applied [1-3, 6, 8, 9, 11, 12, 14]. Moreover, in our study, we also included drug-drug interactions, but excluded intentional overdose cases and the cases in which the causality, according to the WHO criteria, was not at least "probable/likely." This could be one explanation why our estimation of incidence of ADE visits to the ED is lower than in some other studies.

The ADE-related hospitalization rate in our study was $20.8 \%$. This is lower than the $30.9 \%$ reported by Hafner et al. in the U.S. [14] and slightly higher than in one study conducted in EDs in Italy $(19.1 \%)[15,28]$.

Several studies suggested that old age and female gender might be risk factors for hospital admission caused by ADEs [29]. In our investigation, women and patients in the age groups of 30-39 and 60-69 years were significantly associated with ADEs. The association of ADEs with women may be partly attributable to the higher outpatient drug-prescription rate in women, as confirmed both in our and in other studies [3, 26, 30], whereas the association between patients in the 30-39 age group and ADE may be attributable to the higher proportion of self-medicationassociated events (particularly NSAIDs intake). In fact, patients themselves can play a significant role in the occurrence of adverse drug reactions [31]. Patients should also reject the idea that there is a "pill for every ill" and avoid indiscriminate self-medication and doctor hopping [31].

Advanced age has been suggested to be a risk factor for ADEs [26]. We observed an incidence of ADEs higher in patients of 60-69 years. Probably in these patients the 
increased number of comorbidities and regularly scheduled medications associated with advanced age may explain this effect. A few studies have assessed comorbidity or the number of current medical problems and found associations with ADEs [29, 32, 33]. However, it is difficult to explain the relatively low incidence of ADEs in patients over 70 years. It is possible that older people who suffer from more serious illness are more frequently hospitalized or referred to tertiary care units.

Our finding that ADE-related ED visits more frequently affected the skin (34.21\% of total events) and the gastrointestinal system $(21.05 \%)$ is in agreement with a previous report [21]. The drugs involved were antibiotics, NSAIDs, and agents acting on the renin-angiotensin system. In addition, the medications more frequently involved in serious ADEs were antiasthmatics drugs. Given the wide and frequently inappropriate use of antibiotic therapy [34], antibiotics were the drug category most associated with ADE visits in a previous study [34]. NSAIDs were the second drug category most frequently associated to ADE visits. This result could be because most NSAIDs are available over the counter in Italy and are widely used in self-medication [35]. Nimesulide was the NSAID most frequently associated with ADEs; this observation might be explained by the wide use of this drug in Italy. Although nimesulide was involved in 14 ADEs, its serious ADE rate was similar to that of other NSAIDs. Moreover, nimesulide was not associated with any hepatotoxic reaction in our study. According to the literature, the ADEs observed in our study are judged to be preventable.

\section{Limitations of the study}

Our study has some limitations. First, intra- and interrater agreement tests were not performed during the intensive course on theoretical and practical aspects of pharmacovigilance in emergency departments.

Another limitation was that the data were collected through a patient interview, so the patient's report may contain incorrect clinical attributions of symtoms to specific medicines. However, in our study, the diagnoses made by the ED physician were then verified by a medical committee through review of the ED forms in doubtful cases. Thus, we relied on the clinical experience and judgment of the clinical pharmacologist for classifying drug-related events.

In conclusion, our study shows that ADEs are an important public health problem in industrialized countries. Moreover, it shows that ADEs affect hospital admission rates and reinforces the significance of drug-induced disease as a public health problem. Efforts should be made to reduce ADEs through educational strategies aimed at improving awareness of the importance of pharmacovigilance among health professionals. In fact, according to Benichou [36] "a physician who cannot recognize an ADE represents a further risk factor."

Our study also confirms the validity of hospital EDs for surveys of ADEs. Using ED visits to study these events could lead to a better understanding of drug-related problems that arise from general practitioners' prescriptions. Therefore, further studies on large samples of patients are needed to better evaluate the incidence of ADEs in ED visits and to reduce and prevent drug-related injuries. This message should be communicated to relevant health-care policy-markers.

Acknowledgements The authors thank the monitors for data collection and the physicians of the 10 hospital EDs involved in the study: Azienda Ospedaliera (A.O.) A Cardarelli, Napoli, A.O. S. Maria degli Incurabili di Napoli, Presidio Ospedaliero (P.O) Loreto Mare di Napoli, A.O. Pellegrini di Napoli, A.O. San Paolo di Napoli, A.O. San Giuseppe Moscati di Avellino, A.O. G. Rummo di Benevento, A.O. San Sebastiano di Caserta, AA.OO.RR. San Giovanni di Dio e Ruggi d'Aragona di Salerno, and Ospedale San Leonardo di Castellammare di Stabia. We are grateful to Jean Ann Gilder for text editing. This study was supported by grants from Regione Campania (Delibera Giunta Regionale no. 6458 del 31/11/2001).

\section{References}

1. Prince BS, Goetz CM, Rihn TL, Olsky M (1992) Drug-related emergency department visits and hospital admissions. Am J Hosp Pharm 49(7):1696-1700

2. Einarson TR (1993) Drug-related hospital admissions. Ann Pharmacother 27(7-8):832-840

3. Roughead EE, Gilbert AL, Primrose JG, Sansom LN (1998) Drug-related hospital admissions: a review of Australian studies published 1988-1996. Med J Aust 168(8):405-408

4. Schneeweiss S, Hasford J, Göttler M, Hoffmann A, Riethling AK, Avorn J (2002) Admissions caused by adverse drug events to internal medicine and emergency departments in hospitals: a longitudinal population-based study. Eur J Clin Pharmacol 58 (4):285-291

5. Bergman U, Wiholm BE (1981) Drug-related problems causing admission to a medical clinic. Eur J Clin Pharmacol 20(3):193200

6. Mitchell AS, Henry DA, Sanson-Fisher R, O'Connell DL (1988) Patients as a direct source of information on adverse drug reactions. BMJ 297(6653):891-893

7. Mannesse CK, Derkx FH, de Ridder MA, Man in 't Veld AJ, van der Cammen TJ (2000) Contribution of adverse drug reactions to hospital admission of older patients. Age Ageing 29(1):35-39

8. Stoukides CA, D’Agostino PR, Kaufman MB (1993) Adverse drug reaction surveillance in an emergency room. Am J Hosp Pharm 50(4):712-714

9. Dennehy CE, Kishi DT, Louie C (1996) Drug-related illness in emergency department patients. Am J Health Syst Pharm 53 (12): $1422-1426$

10. Schneitman-McIntire O, Farnen TA, Gordon N, Chan J, Toy WA (1996) Medication misadventures resulting in emergency department visits at an HMO medical center. Am J Health Syst Pharm 53(12):1416-1422 
11. Smith KM, McAdams JW, Frenia ML, Todd MW (1997) Drugrelated problems in emergency department patients. Am J Health Syst Pharm 54(3):295-298

12. Raschetti R, Morgutti M, Menniti-Ippolito F, Belisari A, Rossignoli A, Longhini P, Guidara C (1999) Suspected adverse drug events requiring emergency department visits or hospital admission. Eur J Clin Pharmacol 54:959-963

13. Malhotra S, Jain S, Pandhi P (2001) Drug-related visits to the medical emergency department: a prospective study from India. Int J Clin Pharmacol Ther 39(1):12-18

14. Hafner JW, Belknap SM, Squillante MD, Bucheit KA (2002) Adverse drug events in emergency department patients. Ann Emerg Med 39(3):258-267

15. Capuano A, Motola G, Russo F, Avolio A, Filippelli A, Rossi F, Mazzeo F (2004) Adverse drug events in two emergency departments in Naples, Italy: an observational study. Pharmacol Res 50 (6):631-636

16. Hohl CM, Dankoff J, Colacone A, Afilalo M (2001) Polypharmacy, adverse drug-related events, and potential adverse drug interactions in elderly patients presenting to an emergency department. Ann Emerg Med 38(6):666-671

17. Wasserfallen J, Livio F, Buclin T, Tillet L, Yersin B, Biollaz J (2001) Rate, type, and cost of adverse drug reactions in emergency department admissions. Eur J Intern Med 12(5):442447

18. Patel P, Zed PJ (2002) Drug-related visits to the emergency department: how big is the problem? Pharmacotherapy 22(7):915923

19. Queneau P, Bannwarth B, Carpentier F, Guliana JM, Bouget J, Trombert B, Leverve X, Lapostolle F, Borron SW, Adnet F, Association Pédagogique Nationale pour l'Enseignement de la Thérapeutique (APNET) (2007) Emergency department visits caused by adverse drug events: results of a French survey. Drug Safety 30(1):81-88

20. Gurwitz JH, Field TS, Judge J, Rochon P, Harrold LR, Cadoret C, Lee M, White K, LaPrino J, Erramuspe-Mainard J, De Florio M, Gavendo L, Auger J, Bates DW (2005) The incidence of adverse drug events in two large academic long-term care facilities. Am J Med 118(3):251-258

21. Olivier P, Boulbés O, Tubery M, Lauque D, Montastruc J-L, Lapeyre-Mestre M (2002) Assessing the feasibility of using an adverse drug reaction preventability scale in clinical practice: a study in a French emergency department. Drug Safety 25 (14): $1035-1044$

22. Wasserfallen JB, Livio F, Buclin T, Tillet L, Yersin B, Biollaz J (2001) Rate, type, and cost of diverse drug reactions in emergency department admissions. Eur J Intern Med 12:442-447
23. Nebeker JR, Barach P, Samore MH (2004) Clarifying adverse drug events: a clinician's guide to terminology, documentation, and reporting. Ann Intern Med 140(10):795-801

24. Schumock GT, Thornton JP (1992) Focusing on the preventability of adverse drug reactions. Hosp Pharm 27:538

25. Pouyanne P, Haramburu F, Imbs JL, Begaud B (2000) Admissions to hospital caused by adverse drug reactions: cross sectional incidence study. French Pharmacovigilance Centres. BMJ 320 (7241): 1036

26. Hallas J, Harvald B, Gram LF, Grodum E, Brosen K, Haghfelt T, Damsbo N (1990) Drug related hospital admissions: the role of definitions and intensity of data collection, and the possibility of prevention. J Intern Med 228(2):83-90

27. Lazarou J, Pomeranz BH, Corey PN (1998) Incidence of adverse drug reactions in hospitalized patients: a meta-analysis of prospective studies. JAMA 279(15):1200-1205

28. Trifirò G, Calogero G, Ippolito FM, Cosentino M, Giuliani R, Conforti A, Venegoni M, Mazzaglia G, Caputi AP (2005) Adverse drug events in emergency department population: a prospective Italian study. Pharmacoepidemiol Drug Saf 14(5):333-340

29. Field TS, Gurwitz JH, Harrold LR, Rothschild J, DeBellis KR, Seger AC, Auger JC, Garber LA, Cadoret C, Fish LS, Garber LD, Kelleher M, Bates DW (2004) Risk factors for adverse drug events among older adults in the ambulatory setting. J Am Geriatr Soc 52(8):1349-1354

30. Gandhi TK, Bates DW, Burstin HR et al (1998) Drug complications in outpatients. J Gen Intern Med 13(suppl 1):46

31. Gwee MC (1993) Prevention of adverse drug reactions: role of the patient (consumer). Ann Acad Med Singap 22(1):90-93

32. Grymonpre RE, Mitenko PA, Sitar DS et al (1988) Drugassociated hospital admissions in older medical patients. J Am Geriatr Soc 36:1092-1098

33. Gerety MB, Cornell JE, Plichta DT et al (1993) Adverse events related to drugs and drug withdrawal in nursing home residents. $\mathrm{J}$ Am Geriatr Soc 41:1326-1332

34. Mazzaglia G, Caputi AP, Rossi A et al (2003) Exploring patientand doctor-related variables associated with antibiotic prescribing for respiratory infections in primary care. Eur J Clin Pharmacol 59:651-657

35. Traversa G, Bianchi C, Da Cas R, Abraha I, Menniti-Ippolito F, Venegoni M (2003) Cohort study of hepatotoxicity associated with nimesulide and other non-steroidal anti-inflammatory drugs. Br Med J 327:18-22

36. Benichou C, Danan G, Flahault A (1993) Causality assessment of adverse reactions to drugs-II. An original model for validation of drug causality assessment methods: case reports with positive rechallenge. J Clin Epidemiol 46(11):1331-1336 